May Elsayyad

\title{
Bargaining over Tax Information Exchange
}

Max Planck Institute for Tax Law and Public Finance

Working Paper 2012 - 02

February 2012

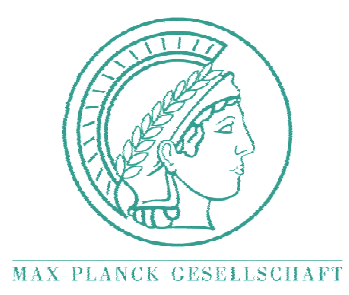

Max Planck Institute for

Tax Law and Public Finance

Department of Business and Tax Law

Department of Public Economics

http:/ / www.tax.mpg.de 
Working papers of the Max Planck Institute for Tax Law and Public Finance Research Paper Series serve to disseminate the research results of work in progress prior to publication to encourage the exchange of ideas and academic debate. Inclusion of a paper in the Research Paper Series does not constitute publication and should not limit publication in any other venue. The preprints published by the Max Planck Institute for Tax Law and Public Finance represent the views of the respective author(s) and not of the Institute as a whole. Copyright remains with the author(s).

Max Planck Institute for Tax Law and Public Finance

Marstallplatz 1

D-80539 Munich

Tel: $\quad+498924246-0$

Fax: $\quad+498924246-501$

E-mail: ssrn@tax.mpg.de

http://www.tax.mpg.de 


\title{
Bargaining over Tax Information Exchange*
}

\author{
May Elsayyad ${ }^{\dagger}$ \\ First Version: February 2012 \\ (This version: March 2012)
}

\begin{abstract}
This paper empirically studies recent treaty signings between tax havens and OECD countries as the outcome of a bargaining process over treaty form. Havens can decide not to sign an agreement, to sign a tax information exchange agreement or to sign a double taxation convention. We use a highly stylized bargaining model to develop testable hypotheses with regards to the type of agreement signed. We show that the main determinants of treaty signing are a haven's bargaining power and good governance. We show that it is easier to renegotiate an already existent treaty to include information exchange than to pressure countries with no existent agreement.
\end{abstract}

${ }^{*}$ The author would like to thank Nadja Dwenger, Kai Konrad and Salmai Qari for helpful comments and suggestions. She gratefully acknowledges financial support from the Deutsche Forschungsgemeinschaft through GRK 801. The usual caveat applies.

${ }^{\dagger}$ Max Planck Institute for Tax Law and Public Finance, Munich, and Munich Graduate School of Economics, University of Munich. E-mail: may.elsayyad@tax.mpg.de. 


\section{Introduction}

Since the financial crisis, countries have shown a renewed interest in combatting international tax evasion. In fact, during the 2009 G20 Summit, countries renewed their commitments towards fighting secrecy jurisdictions by stating that the "era of bank secrecy is over" and that they "stand ready to deploy sanctions" against non-complying secrecy jurisdictions. ${ }^{1}$ Countries classified as tax havens answered to the pressure increase with a surge in bilateral agreements which contain information exchange clauses. However, the choice of treaty partner and type of bilateral information exchange agreement signed has remained unclear. This is particularly interesting, as there are two different types of agreements which allow for information exchange upon request that can be signed: a double taxation convention (DTC) and a Tax Information Exchange Agreement (TIEA). This paper studies the mechanism driving recent treaty signings between tax havens and OECD countries.

Given that a tax haven would rather sign a treaty which also facilitates cross-border investment (DTC) than sign a treaty which only regulates information exchange (TIEA), this paper analyzes the main factors determining the signing of an agreement as the outcome of a bargaining process between tax havens and high tax countries. We use a highly stylized bargaining model to develop testable hypotheses with regards to the type of agreement signed. We show that the main determinants of the outcome of a bargaining framework are the general bargaining position of a tax haven versus a high tax country, the effectiveness of the defensive measures that can be used by the high tax country against a tax haven and the share of capital which is evaded in the tax haven country. We argue that the respective bargaining positions are a function of each country's respective economic position, while the effectiveness of the defensive measures are a function of the strength of the bilateral relationship. We show that a stronger bargaining position of the tax haven should lead to a more advantageous signing from the perspective of the haven, while an increase in the effectiveness of the defensive measures shifts the bargaining outcome more to the liking of the high tax country.

\footnotetext{
${ }^{1}$ See G20 (2009) p.4.
} 
The empirical analysis shows that the main drivers of treaty signing are haven-specific characteristics such as economic strength and good governance, the fact that bilateral similarity and geographical proximity characteristics seem to be unrelated to treaty outcomes, and that the bilateral financial relationship variables play a role albeit a weaker one compared to the haven-specific characteristics.

There are a few theoretical contributions on countries' incentives to exchange information that have focussed on the question of the optimal use of an information exchange clause versus a withholding tax regime. ${ }^{2}$ A main insight of these papers is that larger countries have a stronger incentive to pursue an information exchange regime rather than smaller countries. Bacchetta and Espinosa (2000), for example, investigate under which circumstances countries are more likely to sign a tax treaty and when an information exchange clause will be added to the treaty. In a simple model with two asymmetric countries and repeated interactions between governments, they show that an information exchange clause will not be used when there is a reciprocity requirement, when there is a high costs of negotiations, when there is a cost of providing information or when there are one way capital flows. Consequently, a rationale for the reluctance of tax havens to sign any type of agreement is provided, but there is no explanation for the different types of agreements signed. This paper argues that treaties and treaty types are outcomes of a bargaining process. This view point is also applied by Chisik and Davies (2004). In their paper countries bargain over a withholding tax for foreign owned capital. Their paper focusses on how bargaining can affect the agreed upon withholding taxes and shows that greater asymmetry in FDI activity increases the negotiated tax rates. The analysis is thus driven by treaties already signed but disregards the cases where treaties have not been signed. In contrast, this paper provides a possible explanation of why no agreement is signed. Another relevant study on tax treaty formation is Ligthart and Voget (2011), which empirically investigates the determinants

\footnotetext{
${ }^{2}$ The main contributions are Bacchetta and Espinosa (1995), Bacchetta and Espinosa (2000), Huizinga and Nielsen (2002), Keen and Ligthart (2006) and Keen and Ligthart (2007) .
} 
of tax treaty formation using a panel dataset on 17766 unique country pairs. In their study they find that the main driver of DTC signings is the avoidance of double taxation and that information exchange plays a rather small role. Their paper, however, disregards the fact that the relationship between any two countries that are not tax havens, is an inherently different one than in the case of a country pair, which consists of one high tax country and a tax haven. Specifically, while a signing of a tax treaty for two non-tax haven economies can be mutually advantageous, a treaty between a tax haven and a high tax country cannot be viewed in the same vein. In this paper, we isolate country pair constellations that include a high tax country and a tax haven, allowing a more thorough investigation of the determination of these types of agreements.

Next to the literature on tax treaties and the inclusion of an information exchange clause, our study is also related to the general tax haven literature. While this strand of literature has mainly concentrated on the welfare effects of the existence of tax havens, ${ }^{3}$ in this literature we are mostly related to Elsayyad and Konrad (2011). Their paper presents a competition theory framework which tackles the question of the optimal timing of the fight against tax havens. The gist of their paper relies heavily on the notion that a sequential approach to closing down tax havens is costly and in some cases welfare decreasing as the subsequent closing down of tax havens alters the competition for mobile capital between tax havens making it more profitable to remain the last tax haven standing. The fight against tax havens has also been tackled in the empirical literature, mainly by Huizinga and Nicodeme (2004), Kudrle (2009) and most recently Johannessen and Zucman (2012) who attempt to evaluate how the signing of tax information exchange agreements and the blacklisting of tax havens have affected international deposits. ${ }^{4}$

\footnotetext{
${ }^{3}$ Desai et al. (2006b), Desai et al. (2006a),Hong and Smart (2010) and Johannesen (2010) for notable examples of a positive view on tax havens and Slemrod and Wilson (2009) and Torvik (2009) for a negative view on tax havens. For a survey see Dharmapala (2008).

${ }^{4}$ The first two studies do not find a significant effect of the OECD's fight against tax havens. However, both studies use data that before the recent surge in signings starting in 2009. Johannessen and Zucman (2012) estimate a decline international deposits in reaction to a signing of a TIEA but also an increase in deposits to countries not complying
} 
The previous papers present TIEA signings as an exogenous variable, while our paper treats the treaty formation as the endogenous outcome of a bargaining process that in turn is affected by the level of international deposits held in each tax haven country.

The paper is structured as follows: section 2 introduces the institutional set up of tax treaty signing, section 3 presents the analytical framework and derives the theoretical hypotheses, section 4 presents the estimation strategy and discusses the dependent and explanatory variables, section 5 presents the regression results and provides a robustness analysis. Section 6 concludes.

\section{Institutional setting}

Agreement form. In an effort to show commitment to tax transparency and exchange of information, tax havens can agree to sign one of two agreements: a double taxation convention (DTC), also called income agreements, or, a tax information exchange agreement (TIEA). Both agreements can include provisions that regulate tax-related information exchange. The most widely accepted legal basis for bilateral exchange of information for tax purposes is Article 26 of the OECD Model Tax Convention. It creates an obligation to exchange information that is foreseeably relevant to the correct application of a tax convention as well as for purposes of the administration and enforcement of the domestic tax laws of the contracting states. A signing of a tax treaty which includes an information exchange clause allows for the correct estimation of each individual's income and, consequently, the correct tax burden. The two agreements, however, differ in their scope. While a DTC is mainly signed to foster and alleviate the double taxation of cross-border investment and can include an article that regulates information exchange, a TIEA only regulates the flow of information between a tax haven and a high tax country and does not include other dimensions. Thus, from the perspective of a tax haven, there is a natural preference ranking between the different outcomes. A tax haven would most prefer not to sign an agreement

to the international tax and transparency standards. 
which complicates and impedes its capital concealment services. But if it would have to comply to one of the two agreements, the signing of a DTC would be preferable to the signing of a TIEA. This is due to the fact that there is a potential cross-border investment gain from signing a DTC, but a TIEA does not yield any such advantage. ${ }^{5}$

Defensive measures. To induce tax havens to comply with international tax and transparency standards, the OECD report on Harmful Tax Practices also proposed a number of defensive measures that can be used against non-complying jurisdictions. ${ }^{6}$ The defensive measures can be grouped into three categories: domestic tax measures, non-related tax measures and tax treaty measures. Domestic tax measures can be characterized by a punitive discrimination of foreign income originating from, or flowing to, a noncomplying jurisdiction. ${ }^{7}$ Non-tax treaty measures focus on the discouragement of financial institutions from investment in non-cooperative jurisdictions. Finally, tax treaty measures can take the form of a termination tax treaties with countries that are not prepared to engage in full exchange of information. Here, it becomes clear that such defensive measures can be used in order tor pressure havens into complying and that the potential effectiveness of the defensive measures is a function of the strength and scope of the bilateral relationship.

\section{A simple bargaining framework}

In order to develop testable hypotheses, we develop a highly stylized model of bargaining over the type of agreement signed between a high tax country and

\footnotetext{
${ }^{5}$ The EU Savings Tax Directive is another information exchange scheme used by EU countries, where countries either commit to an automatic exchange of information or a withholding tax regime on income of residents from other EU countries. This initiative is clearly multilateral and cannot be assumed to work in the same way as the bilateral agreements. For this reason, we only control for it in the robustness checks section.

${ }^{6}$ See OECD (1998) p.40-50.

${ }^{7} \mathrm{~A}$ main example is the new French legislation, where dividends, service fees and royalties paid by a French entity to a beneficiary in a blacklisted country will face a $50 \%$ withholding tax.
} 
a tax haven. We extend the driving mechanism first introduced in Bacchetta and Espinosa (2000) to include defensive measures which influence the tax haven's business negatively and allow for bargaining over the share of evaded income that can be taxed domestically due to information exchange. ${ }^{8}$

We consider a world with two countries, a high-tax country $S$ and a tax haven $H$. Country $S$ would like to tax the capital stock of its residents. We assume that due to lax regulation and strong bank secrecy rules, tax haven $H$ provides capital concealment services that allow residents of the high-tax country to evade taxes in their home country but suffers reputational and/or financial damages due to being classified as a tax haven. Capital $\bar{K}$ is solely owned by residents of $S$ and is either invested in $S$ and denoted by $K^{d}$ or evaded in $H$ and denoted by $K^{e}$;

$$
\bar{K}=K^{d}+K^{e}
$$

Thus, the income of the tax haven amounts to

$$
Y_{H}=p K^{e}-D
$$

which consists of the revenue from concealing the share of capital $K^{e}$ at price $p$ minus the defensive measures $D$, which the high-tax country employs in order to make a tax haven's concealment services less attractive. ${ }^{9}$

Due to the concealment services provided by the haven, $S$ can only tax capital invested domestically. Country $S$ 's income amounts to

$$
Y_{S}=t K^{d}
$$

While it is also possible to assume a different payoff function for the high tax country $S$, the main driver of the fight against tax havens is a revenue maximizing one, and, thus, we abstract from other motives of taxation.

We assume that countries bargain over $\alpha \in[0,1]$, which denotes the share

\footnotetext{
${ }^{8}$ Notice that a DTC should always have a lower share of evaded capital that can be taxed domestically than a TIEA as cross-border investment is facilitated.

${ }^{9}$ Note, that $p K^{e}-D \geq 0$. If not then, it would not make sense for the haven to remain active, as the damages that the haven has to suffer would be too high.
} 
of evaded capital which can, after the signing of the treaty, be taxed by $S$. For the tax haven $H$, a signing of a treaty means the reduction of its income from capital concealment services by $\alpha$ and no longer facing defensive measures by $S$. For the high-tax country $S$, a signing of the treaty means a higher amount of capital that it can tax domestically. Thus, $H^{\prime} s$ income after the signing of a treaty amounts to

$$
Y_{H}^{*}=(1-\alpha) p K^{e},
$$

and $S^{\prime} s$ income after the signing of a treaty amounts to

$$
Y_{S}^{*}=t\left(K^{d}+\alpha K^{e}\right)
$$

It is straightforward to see that, while the high-tax country would favor a high share of capital to be taxed domestically, if unconstrained then $\alpha=1$, a tax haven's income is decreasing in $\alpha$ and, thus, given the unconstrained choice, its optimal $\alpha$ would amount to zero.

We use the generalized Nash bargaining solution to derive the results of the bargaining process. ${ }^{10}$ Consequently, the solution can be found by choosing an $\alpha$, which maximizes a weighted product of the two countries' gains from treaty formation. Thus, $\alpha$ must satisfy:

$$
\alpha(\gamma) \in \arg \max \left[\left(Y_{H}^{*}-Y_{H}\right)^{\gamma}\left(Y_{S}^{*}-Y_{S}\right)^{1-\gamma}\right]
$$

where $\gamma$ represents the relative bargaining power of the tax haven $H$.

Taking the first derivative with respect to $\alpha$ yields

$$
\alpha=\frac{(1-\gamma) D}{p K^{e}}
$$

Note that when $\gamma=0$, the high-tax country has all the bargaining power and the chosen share will be as close to $\alpha=1$ as possible. Analogously, when the tax haven enjoys all the bargaining power due to $\gamma=1$ the optimal $\alpha$ is 0 .

\footnotetext{
${ }^{10}$ Given that the observed country pairs are inherently asymmetric, we abandon Nash's symmetry axiom.
} 
From equation (7), we can derive a set of comparative statics, which helps us to determine the testable hypotheses.

Proposition 1 Suppose $H$ and $S$ bargain over the share of formerly evaded capital to be taxed by $S$, then the negotiated share $\alpha$ is:

(i) decreasing in $\gamma$,

(ii) decreasing in $K^{e}$ and

(iii) increasing in $D$.

Proof. Differentiating (7) with respect to $\gamma, D$ and $K^{e}$ yields

$$
\begin{aligned}
\frac{\partial \alpha}{\partial \gamma} & =-\frac{D}{p K^{e}}<0 \\
\frac{\partial \alpha}{\partial K^{e}} & =-\frac{(1-\gamma) D}{p\left(K^{e}\right)^{2}}<0 \\
\frac{\partial \alpha}{\partial D} & =\frac{(1-\gamma)}{p K^{e}}>0
\end{aligned}
$$

The derived comparative statics allow for the identification of the main drivers of the bargaining outcome. It is straightforward that an increase in the bargaining power of the haven reduces the optimal share of $\alpha$ and shifts it more to the tax haven's liking. An increase in the share of evaded capital in the tax haven works in the same direction. This is quite intuitive, as the gains from treaty formation increase for the high-tax country and, thus, a tax haven can push a more favourable outcome. A ceteris paribus increase in the defensive measures, also shifts $\alpha$ quite intuitively. In this case, an increase in the defensive measures is connected with an increase in the gains of treaty formation for the haven. Here, the tax haven is unable to profit from its tax haven business and is thusly more prone to accept a higher $\alpha$ to avoid the defensive measures.

Consequently, we are able to show that the main determinants of the outcome of a bargaining framework are the general bargaining position of a tax haven vs. a high tax country, the effectiveness of the defensive measures that can be used by the high tax country against a tax haven and 
the share of capital which is evaded in the tax haven. For the succeeding empirical analysis, we argue that the bargaining positions are a function of each country's respective economic position, while the effectiveness of the defensive measures are a function of the strength of the bilateral relationship. A stronger economic position of a tax haven should decrease $\alpha$ and, thus, one should observe more outcomes to the haven's liking. The impact of the defensive measures can be seen as an increasing function of the strength of the economic relationship.

In the following sections, we empirically analyse the effect of the different tax havens' specific economic characteristics and the bilateral relationship on the bargaining outcome.

\section{Empirical analysis}

\subsection{Estimation strategy}

While the optimal share of capital $\alpha_{i j}$ for tax haven $i$ and high tax country $j$ cannot be directly observed, what can be observed are three different outcomes: For a given haven-high-tax country pair, one can either observe no agreement, a DTC or a TIEA. We argue that $\alpha_{i j}$ is an underlying latent variable, that can be mapped into agreement form. We purport that low levels of $\alpha_{i j}$ correspond to no treaty, middle levels of $\alpha_{i j}$ correspond to a DTC and high levels of $\alpha_{i j}$ correspond to a TIEA. The ordinal character of the variable is based on the institutional set up presented in section 2 . The continuous latent response $\alpha_{i j}^{*}$ is related to the ordinal agreement form $y_{i j}$ via the threshold model

$$
y_{i j}=\left\{\begin{array}{ccc}
\text { No agreement } & \text { if } & \alpha_{i j}^{*} \leq \kappa_{1} \\
\text { DTC } & \text { if } & \kappa_{1}<\alpha_{i j}^{*} \leq \kappa_{2} \\
\text { TIEA } & \text { if } & \kappa_{2}<\alpha_{i j}^{*} .
\end{array}\right.
$$

As shown in the previous section, the bargaining outcome is a function of the evaded capital, the general bargaining power of the tax haven and the effectiveness of the defensive measures. While it is inherently difficult, to 
determine the share of the evaded income, our main explanatory variables run along the lines of determining the actual bargaining power of the tax havens and the possible effectiveness of the defensive measures. We argue that the actual bargaining power of a haven can be traced to its own position and characteristics, while the pressure that a high-tax country can exert on it is determined by the strength of its bilateral relationship. Our empirical approach, thus, needs to encompass both unilateral and bilateral variables that explain treaty formation. In effect, we would like to regress agreement form on a tax haven's bargaining power and the strength of its bilateral relationship with the high-tax haven. For this, we specify a random intercept model for the latent response $\alpha_{i j}^{*}$ :

$$
\alpha_{i j}^{*}=x_{i j}^{\prime} \beta+u_{i}+\epsilon_{i j}
$$

$x_{i j}$ is a column of exogenous variables that include both haven specific and country pair specific variables, while $\beta$ is a conformable vector of coefficients, $u_{i}$ is a haven specific random effect and $\epsilon_{i j}$ is the usual independent and identically distributed error term. We assume that the haven specific random effect $u_{i}$ and $\epsilon_{i j}$ have normal distributions and are independent. To fit the random effects ordered probit model, we use a generalized latent linear and mixture model (GLAMM) procedure. ${ }^{11}$

\subsection{Agreement Form}

For the dependent variable, we consider all possible country pair constellations between OECD countries, which are not on the tax haven list themselves, and tax havens. ${ }^{12}$ This amounts to $\left(27 \mathrm{OECD}^{*} 49 \mathrm{TH}\right)=1323$ individual country pair observations. We combine the OECD's tax haven definition with the list of countries provided in Appendix 2 of Hines and Rice (1994). ${ }^{13}$

\footnotetext{
${ }^{11}$ See Rabe-Hesketh and Skrondal (2008).

${ }^{12}$ Note, that Belgium, Luxembourg and Switzerland are OECD countries and have been found to fall under the tax haven definition. To ensure that our results are not driven by these countries, we have in some empirical specification excluded them from the analysis.

${ }^{13} \mathrm{~A}$ list of countries and territories classified as tax havens under this definition are presented in the Appendix.
} 
For each generated pair, we check if either a DTC which incorporates a strong information exchange or a TIEA has been signed. The main sources of these agreements are the International Bureau for Fiscal Documentation Database and the OECD Global Forum for Transparency for Tax Purposes.

We restrict our dataset to this subset of countries for two reason: First, the main fight against tax havens has been initiated by OECD countries and main developments have always been spearheaded by the OECD Forum. Second, while the TIEA model framework and Article 26 can be introduced and signed between any two countries, they have been mainly developed to combat international tax evasion and the concealment services of haven jurisdictions.

Out of the 1323 possible country pair observations, 155 DTCs have been signed that include a strong information exchange clause, while 323 TIEAs have been signed. The Bahamas, with 18 TIEAs, has the largest number of TIEAs signed, while Luxembourg tops the list for the highest number of DTCs with a strong information exchange clause signed. A quick look at the signings shows that the Nordic Countries have been particularly active treaty partners. This is partly due to the fact that they adopted a multilateral approach of treaty signing very early. ${ }^{14}$ Due to the fact that the bulk of the agreements have been signed in 2009/2010, there is no meaningful longitudinal variation in this measure and the analysis is restricted to a cross section.

\subsection{Haven-specific characteristics}

General characteristics of the haven have a strong impact on its bargaining position. As previously posited, an increase in a haven's bargaining power should decrease the latent variable $\alpha_{i j}^{*}$ and, thus, be correlated with a stronger share of country pair constellations, where no agreements have been signed or where, at most, a DTC has been signed.

\footnotetext{
${ }^{14}$ In our estimation, one robustness check is to exclude country pair constellations of tax havens with Nordic countries, in order to insure that our results are not driven by the different multilateral approach of the Nordic countries.
} 
A haven's economic strength. A probable indicator of a country's relative economic strength is its GDP, and, for that reason, we have included the GDP of the havens in 2006 (in current USD). The use of GDP in our analysis is particularly advantageous, as it has the widest coverage.

In a robustness check, we add the share of foreign direct investment outflow from the tax haven, as a share of its GDP, as a variable to capture a haven's outward financial activity and disentagle it from its other economic activities. It is to be argued that there is a direct correlation between the financial importance of the country and its bargaining position. Due to the limited coverage of this variable, we analyse it separately.

A haven's bargaining power can be also interpreted as its ability to exert its financial independence. For this reason, we add a dummy variable which indicates if a haven is eligible for official development aid or not. In this case, one can assume that countries eligible for aid are more reliant on the international community and international good will and will, thus, be more prone to comply to the international standards of transparency and information exchange. Consequently, we expect a positive correlation between the share of signed treaties and the types of treaties being signed.

A haven's good governance. Taking into account that the decision to comply with international tax information exchange standards is a function of a country's general good governance, we add a measure of countries' governance institutions developed for the World Bank by Kaufmann et al. (2010). ${ }^{15}$ We have constructed an aggregated index of the world governance indicators for the year 2009, as this dataset has a significantly expanded coverage. In this case, one should expect a positive correlation between a higher good governance index and agreement form, which translates into a low share of country pair observations that have no treaty signed and a high share of country pair observations where a TIEA has been signed.

\footnotetext{
${ }^{15}$ They construct aggregate country-scores for six different elements of country-level governance: Voice and accountability, political stability, government effectiveness, regulatory quality, rule of law and control of corruption. Each of these measures takes values from approx. -2.5 to 2.5 with higher values indicating better governnce. The data is normalized so that the mean across all countries is 0 and the standard deviation is 1 .
} 


\subsection{Country pair-specific characteristics}

Taking into account that agreement form is the outcome of a bilateral process and, thus, cannot be solely explained by unilateral determinants, we include country-pair specific characteristics to determine the scope and strength of the bilateral relationship of each country pair. The bilateral relationship can be characterized by the relative bargaining position of the high-tax country and the effectiveness of the defensive measures that can be used by the hightax country against the tax haven.

Relative bargaining power. To control for the fact that the relative strength of the high-tax country also influences treaty formation and can positively correlate with the possible defensive measures, we include the difference in GDP per capita for each tax haven-OECD country pair. In this regard, we expect that a higher GDP per capita difference should correlate with a higher agreement form and, thus, a larger share of signed agreements should be observed.

Defensive measures. Next to the tax haven blacklist, which has also been used as an instrument to generally pressure all listed tax havens into compliance with OECD transparency standards, country-pair specific pressure should play a stronger role for agreement form outcome. As a guideline for possible bilateral defensive measures, we use the OECD's Harmful Tax Practices Initiative Report's recommendations highlighted in section 2 of this paper. While discriminatory measures can differ from one OECD country to another, it stands to reason that their scope is highly dependent on the importance of the bilateral relationship between a haven and a high tax country. To capture all possible types of financial flows between a tax haven and high-tax country, we add bilateral portfolio outflows from OECD countries to tax havens and bilateral foreign direct investments to our analysis. ${ }^{16}$ The third type of defensive measure pertains to the status of the haven as

\footnotetext{
${ }^{16}$ For non-tax treaty related flows, one could add bilateral trade and bilateral official development assistance to the analysis. However, both measures are only availabe for a very few number of countries.
} 
a treaty partner. The report proposes the scrapping of beneficial tax treaty arrangements in order to pressure non-complying jurisdictions. For this reason, we have added a dummy variable which records if a treaty was in force before 1998 and, thus, if its possible termination could be used as method of pressuring tax havens into compliance. In our data, there have been 38 cases of treaty termination, of which 30 have resulted in new tax information exchange agreements, while 8 country pairs have remained without a treaty. Furthermore, 147 treaties have been renegotiated to include the stronger information exchange clause. Taking our cue from the theoretical framework, we expect the defensive measures to positively correlate with treaty outcome and, thus, a higher share of country pairs should have either a DTC or a TIEA.

Control variables. We add bilateral control variables that should account for country pair similarity. Specifically we have added a dummy variable for common language, and a bilateral distance measure. For the missing bilateral distance measures, we use the distance of the nearest country available. It is unclear how mobile capital should react to distance, given that most tax havens are islands and, thus, rather isolated. For the common language variable, if one assumes that evaded capital is more likely to flow to countries that share the same language due to an easier understanding of the environment and culture, one can assume a negative correlation between agreement form and common language. ${ }^{17}$

\section{Results}

\subsection{Benchmark estimations}

In the following, we present the results of Table 1. Before interpreting the coefficients of the covariates there are two remarks to be made. First, the highly significant estimated cut-off points show the fit of the ordinal assumption on the data. Second, the rather high estimated standard deviations

\footnotetext{
${ }^{17}$ All variables and their sources are described in more detail in the Data Appendix.
} 
Table 1: Benchmark Estimation

\begin{tabular}{|c|c|c|c|}
\hline & (1) & $(2)$ & $(3)$ \\
\hline \multicolumn{4}{|l|}{ Dep. variable: agreement form } \\
\hline \multirow[t]{2}{*}{ Distance } & -0.0735 & -0.0710 & -0.0305 \\
\hline & -0.0485 & $(0.0509)$ & $(0.0539)$ \\
\hline \multirow[t]{2}{*}{ GDP } & $-0.4590^{* *}$ & $-1.3340^{* * *}$ & $-0.8036^{* * *}$ \\
\hline & $(0.1498)$ & $(0.2764)$ & $(0.2058)$ \\
\hline \multirow[t]{2}{*}{ Governance index } & $0.9080 * * *$ & $0.7209^{* * *}$ & $0.9451^{* * *}$ \\
\hline & $(0.1645)$ & $(0.1544)$ & $(0.1643)$ \\
\hline \multirow[t]{2}{*}{ ODA eligibility } & $0.4257^{* * *}$ & 0.1628 & $0.3994^{* *}$ \\
\hline & $(0.1227)$ & $(0.2286)$ & $(0.1999)$ \\
\hline \multirow[t]{2}{*}{ GDP per capita difference } & $0.3597 * * *$ & $0.2813^{* * *}$ & $0.6315^{* * *}$ \\
\hline & $(0.0470)$ & $(0.0663)$ & $(0.0812)$ \\
\hline \multirow[t]{2}{*}{ Common language } & -0.1269 & $-0.2098^{*}$ & $-0.2679^{* *}$ \\
\hline & $(0.1005)$ & $(0.1202)$ & $(0.1274)$ \\
\hline \multirow[t]{2}{*}{ Treaty before 1998} & & $.3917^{* *}$ & $0.4373^{* *}$ \\
\hline & & $(0.1502)$ & $(0.1634)$ \\
\hline \multirow[t]{2}{*}{ Bilateral portfolio outflow } & & $0.1020^{* *}$ & \\
\hline & & $(0.0423)$ & \\
\hline \multirow[t]{2}{*}{ Bilateral FDI } & & & -0.0082 \\
\hline & & & $(0.0400)$ \\
\hline \multirow[t]{2}{*}{$\kappa_{1}$} & $1.6864^{* * *}$ & $1.2762^{* * *}$ & $1.5431^{* * *}$ \\
\hline & $(0.2097)$ & $(0.2380)$ & $(0.2269)$ \\
\hline \multirow{2}{*}{$\kappa_{2}$} & $2.0987 * * *$ & $1.7718^{* * *}$ & $2.0284^{* * *}$ \\
\hline & $(0.2121)$ & $(0.2399)$ & $(0.2316)$ \\
\hline$\tau_{i}$ & 0.9889 & 0.7576 & 0.9765 \\
\hline \multirow{2}{*}{$\begin{array}{r}\text { Log Likelihood } \\
\mathrm{N}\end{array}$} & -832.0007 & -629.0557 & -537.9602 \\
\hline & 1134 & 803 & 730 \\
\hline
\end{tabular}


of the haven-specific random intercept imply a high intra-class correlation in each cluster. As we cluster by haven, this means that there is a strong correlation between the outcomes for each haven, which already hints at the assumption that the haven-specific effects will have a strong impact on agreement form outcome.

The first specification empirically analyzes the relationship between the bargaining position of a tax haven and agreement form. Thus, we include all haven-specific characteristics while controlling for country pair similarity. This means we regress agreement form on the tax haven's GDP, average governance indicator, official development assistance eligibility and difference in GDP per capita between the country pair. In the subsequent specifications, we then add the defensive and bilateral relationship measures to the estimation to determine their correlation with agreement form. The defensive measures include a dummy variable for treaties signed before 1998 and the level of bilateral portfolio investment outflow from an OECD country to a tax haven (specification (2)) or the sum of bilateral foreign direct investment between a tax haven and a high tax country (specification (3)). ${ }^{18}$ As is common in all maximum likelihood estimations, the estimated coefficients cannot be interpreted directly. Nevertheless, they are proportional to the marginal effects and, thus, one can determine the impact of each covariate in relation. Furthermore, the estimated coefficients identify the estimated effect of the variables on the first and last category unambiguously. For illustrational purposes, we present the results of the conditional model here, while the marginal effects of the population averaged model are to be found in Table 7.

Haven-specific characteristics. Both GDP and the average of the havens' governance index show highly significant and robust results. In all of the presented specifications, an increase in GDP by one standard deviation increases the probability for the country pair observation to have no agreement signed and unambiguously decreases the probability of a TIEA being

\footnotetext{
${ }^{18}$ In order not to lose to many observations, we regress each of the bilateral measures separately.
} 
signed. This can be interpreted as an indicator that economically stronger countries are less responsive to pressure and, thus, are more likely to choose not to comply to the international standards of information exchange. An increase in the governance indicator shows the opposite effect. Havens with a higher governance indicator show a smaller probability of not having any agreement and a larger probability of signing TIEAs. This implies that a high governance index is not only correlated with a strong regard for the rule of law and transparency domestically but also a stronger compliance with international standards. The benchmark estimations show also a positive impact of official development aid eligibility on the probability of complying to international tax and transparency standards and signing TIEAs. This supports the claim that havens that are eligible for official development aid are more dependent on international good will and, thus, respond more quickly to pressure.

Country-pair specific characteristics. Differences in GDP per capita which is a country-pair specific variable, also shows a robust and significant correlation with agreement form outcome that is in line with the derived hypotheses. In all specifications, an increase in the difference in GDP per capita of a country pair is correlated with an increase in the likelihood of signing a TIEA. Thus, one can argue that the higher the difference in wealth between a high tax country and a tax haven, the higher the probability of having an agreement and a treaty form which is more advantageous to the high tax country.

With regard to the defensive measures used in our estimation, it seems that the treaty dummy has the strongest impact on agreement form outcome. We observe a significant positive correlation between between the signing of a treaty before 1998 and the inclusion of the strong information exchange clause through renegotiations. Moreso, a higher level of bilateral portfolio outflow from OECD countries to tax havens is also correlated with a higher, albeit small, probability of countries signing TIEAs. Bilateral foreign direct investment between tax havens and the OECD countries seem to be uncorrelated with agreement form. The regressions imply that while treaty-related 
defensive measures have an impact on the outcome of the agreement, financial flows between the the high-tax country and the tax haven do not seem to drive the bargaining decision. This begs the question as to whether the defensive measures have been a successful mechanism of making tax havens comply to international tax information exchange standards or not.

Control variables. Interestingly, the variables added to control for cultural and geographic proximity show, only in the case of the dummy variable common language, a significant effect on agreement form. While distance seems to be unrelated to agreement form, sharing the same language is correlated with a lower probability for the tax haven to comply with international standards and to sign any form of an information exchange agreement. If one assumes that tax havens which share the same language as the high-tax country are more attractive to tax evaders from the high-tax country, then it seems that the estimated effect goes in line with the proposed bargaining model. This is due to the fact an increase in the share of capital evaded in the tax haven reduces the optimal agreed upon share of evaded capital that can subsequently be taxed by the high-tax country.

\subsection{Robustness}

In this section, we examine the robustness of the results of the benchmark estimation. The performed robustness either include more control variables, which might be perceived as affecting the outcome, or exclude some countries from the dataset in order to determine if the results are driven by these countries. All regression tables follow the same specifications as in Table 1.

Haven Foreign Direct Investment Outflow. In the benchmark estimation, the GDP of a tax haven seemed to have a significant impact on agreement form. The GDP variable can be thought of as capturing all economic sectors and not distinguishing between the general economic sectors of the haven economy and the financial sector. Table 3 shows the results of the ordered probit regression for the same specifications as in Table 1 if one 
includes net foreign direct investment outflow of a haven, as a share its GDP. This variable is particularly interesting as it is a clearer indicator for the importance of foreign direct investment for the haven's economy. While the direction of the estimated coefficients of the benchmark estimations remain significant and unchanged, the regressions show that a higher foreign direct investment outflow, as a share of GDP, is correlated with lower agreement forms. More specifically, an increase in a haven's foreign direct investment net outflow, as a share of its GDP, decreases the probability of the signing of a TIEA as well as increases the probability of a haven not complying to international standards and, thus, not signing any type of information exchange agreement. Thus, it seems that the increased openness of the haven with regard to foreign direct investment outflow also increases a haven's bargaining power.

Savings Tax Directive. EU countries have a separate information exchange scheme that runs under the Savings Tax Directive and is also upheld by tax havens which are dependencies of EU countries. Consequently, it is not far-fetched that such an information exchange scheme would have an effect on the information exchange agreement forms. In Table 4, we present the same specifications as in Table 1 but also control for the existence of the Savings Tax Directive between some tax havens and the EU countries in the sample. Interestingly, the inclusion of a dummy variable which indicates if both countries comply to the Savings Tax Directive does not seem to have an affect on agreement form and the estimated effects of the conditional model remained largely unchanged. This is a particularly interesting result as it shows that the Savings Tax Directive is considered to be separate vehicle for information exchange. It also shows that the Savings Tax Directive has not acted as either a substitute for the bilateral agreements or encouraged the signing of such agreements.

Excluding OECD tax havens. In order to account for the fact, that OECD countries that also bear tax haven characteristics might be treated differently, Table 5 provides the conditional effects for the dataset, excluding 
the OECD tax havens Luxembourg, Switzerland and Ireland. Our main variables of interest remain unchanged to the restriction of the dataset. The only change documented is the fact that the common language dummy no longer has a significant negative effect on agreement form, but becomes insignificant.

Excluding Nordic countries. In another robustness check, we exclude country pair constellations that include the Nordic countries: Denmark, Finland, Iceland, Norway and Sweden (Table 6). This is to account for the fact that Nordic countries have a distinctly different procedure of bilateral treaty signing, which has shown particular success. The result of our estimation with regard to dataset excluding the Nordic countries show some marked differences to the previous results. While haven GDP, difference in GDP per capita, haven good governance and bilateral portfolio outflow to the tax haven remain significant and robust to the exclusion of the Nordic countries from the dataset, both the treaty variable and the official development aid eligibility variable become insignificant. This seems to imply that the treaty measure has been largely used by the Nordic countries and has not been put under as much use by the other OECD countries. The fact that the official development aid eligibility dummy variable loses its significance when the Nordic countries are excluded implies that the bulk of the treaties signed by countries that are also eligible to receive official development aid have been mainly signed with the Nordic countries.

\section{Policy implications and conclusion}

A first glimpse on tax haven compliance after the G20 crackdown on tax havens initiated by the G20 London Summit in 2009 shows a strong surge of bilateral agreements between tax havens and high-tax countries implying the success of the initiative. However, the main mechanisms driving the process of treaty signing have remained unclear. In this paper, we present a bargaining framework to analyze treaty formation, taking into account that TIEAs and DTCs, even if both include information exchange clauses, are not the same. Given that DTCs facilitate cross-border investments, they are 
clearly more favourable to a tax haven than a normal TIEA. Furthermore, it is clear that without outside pressure, havens would not pursue the signing of agreements which include an information exchange clause. Thus, taking the natural ordering of the three possible agreement forms into account, we estimate a random intercept ordered probit model to analyze how the potential bilateral defensive measures and a haven's bargaining position and characteristics are correlated with agreement form. We show that the main drivers of the likelihood of a specific agreement are each haven's bargaining power and its average governance index, while bilateral indicators seem to have a smaller impact on agreement form. More specifically, we show that havens with a higher GDP are more likely to not sign any agreements and havens with a high average governance index are more likely to have a TIEA. Official development assistance eligibility seems to also have a positive impact on agreement form, as countries which are eligible for this type of assistance are more likely to have signed TIEAs. This highlights haven's reliance on international good will and, thus, its stronger response to international pressure than countries that are not dependant on such assistance. The case that a haven's foreign direct investment net outflow, as a share of its GDP, is significantly correlated with a lower agreement form is also easily interpreted, as it seems to be a good proxy for the haven's reliance on being a financial hub. Possible defensive measures that should have a stronger impact when the bilateral financial relationship is strong are only significant in the case of bilateral portfolio outflow, whereas, in the case of foreign direct investment, there does not seem to be any significant correlation. The defensive measure which seems to have the strongest impact on agreement form outcome are the tax treaty related measures. We show that if a OECD country and a haven had an agreement in force before 1998 , they are more likely to respond to pressure and accept a renegotiation that includes the stronger form of the information exchange clause.

Taking our results into account, it becomes clear that the perceived recent successes of the G20 crackdown have been mainly due to the active participation of smaller tax havens. Stronger tax havens remain non-compliant and it is their characteristics which mainly define the agreement outcome. The 
financial bilateral relationships in the case of bilateral portfolio investment seem to have a positive impact on agreement form, but the strongest impact, has been on tax havens which had already entered into agreements. Thus, it seems that the OECD needs to develop stronger defensive measures in order to counter the stronger bargaining position of the bigger havens and to achieve results in the fight against international tax evasion.

\section{Tables and Figures}

Table 2: Summary Statistics

\begin{tabular}{cccccc}
\hline Unilateral Variable & Obs & Mean & Std. Dev. & Min & Max \\
\hline ODA Eligibility & 76 & 0.342105 & 0.4775669 & 0 & 1 \\
World Goverance Index Average & 69 & 0.78164 & 0.6446449 & -0.8911266 & 1.81754 \\
FDI net outflow (\%GDP) & 61 & $1.95 \mathrm{E}+10$ & $4.15 \mathrm{E}+10$ & $-7 . \mathrm{E}+09$ & $2 . \mathrm{E}+11$ \\
GDP & 76 & $5.34 \mathrm{E}+11$ & $1.67 \mathrm{E}+12$ & $2 . \mathrm{E}+07$ & $1 . \mathrm{E}+13$ \\
GDP per capita & 76 & 27704.07 & 25229.52 & 185 & 132234 \\
Bilateral Variable & Obs & Mean & Std. Dev. & Min & Max \\
Difference in GDP per capita & 1323 & 25589.26 & 21243.5 & 71 & 124547 \\
Bilateral Portfolio Outflow & 942 & 7637.43 & 38508.48 & -20 & 543887 \\
Bilateral FDI & 848 & 1563.651 & 12508.95 & -4591.076 & 214303 \\
Treaty before 1998 & 1323 & 0.139834 & 0.3469456 & 0 & 1 \\
Distance & 1323 & 4243752 & 3126219 & 7932 & 9985533 \\
Common Language & 1323 & 0.270597 & 0.4444363 & 0 & 1 \\
\hline
\end{tabular}


Figure 1: Number of DTCs and TIEAs signed by haven country.

\begin{tabular}{|c|c|c|c|}
\hline Tax Haven & No Agreement & DTC & TIEA \\
\hline Andorra & 15 & 0 & 12 \\
\hline Anguilla & 13 & 0 & 14 \\
\hline Antigua \& Barbuda & 14 & 1 & 12 \\
\hline Aruba & 18 & 3 & 6 \\
\hline Bahamas & 9 & 0 & 18 \\
\hline Bahrain & 14 & 8 & 5 \\
\hline Barbados & 19 & 7 & 1 \\
\hline Belize & 16 & 1 & 10 \\
\hline Bermuda & 10 & 7 & 10 \\
\hline British Virgin Islands & 13 & 7 & 7 \\
\hline Cayman Islands & 11 & 5 & 11 \\
\hline Cook Islands & 15 & 1 & 11 \\
\hline Cyprus & 26 & 1 & 0 \\
\hline Dominica & 13 & 0 & 14 \\
\hline Gibraltar & 12 & 0 & 15 \\
\hline Grenada & 15 & 1 & 11 \\
\hline Guernsey & 10 & 7 & 10 \\
\hline Hong Kong & 17 & 10 & 0 \\
\hline Ireland & 24 & 3 & 0 \\
\hline Isle of Man & 8 & 9 & 10 \\
\hline Jersey & 10 & 9 & 8 \\
\hline Jordan & 27 & 0 & 0 \\
\hline Lebanon & 27 & 0 & 0 \\
\hline Liberia & 23 & 0 & 4 \\
\hline Liechtenstein & 15 & 0 & 12 \\
\hline Luxembourg & 10 & 17 & 0 \\
\hline Macao & 21 & 0 & 6 \\
\hline Maldives & 27 & 0 & 0 \\
\hline Malta & 21 & 6 & 0 \\
\hline Marshall Islands & 18 & 2 & 7 \\
\hline Mauritius & 23 & 3 & 1 \\
\hline Monaco & 15 & 1 & 11 \\
\hline Montserrat & 17 & 1 & 9 \\
\hline Naurı & 27 & 0 & 0 \\
\hline Netherlands Antilles & 14 & 4 & 9 \\
\hline Niue & 27 & 0 & 0 \\
\hline Panama & 19 & 7 & 1 \\
\hline St. Kitt \& Nevis & 13 & 1 & 13 \\
\hline St. Lucia & 15 & 0 & 12 \\
\hline St. Vincent \& the Grenadines & 13 & 0 & 14 \\
\hline Samoa & 19 & 2 & 6 \\
\hline San Marino & 11 & 4 & 12 \\
\hline Seychelles & 25 & 2 & 0 \\
\hline Singapore & 14 & 13 & 0 \\
\hline Switzerland & 15 & 12 & 0 \\
\hline Tonga & 27 & 0 & 0 \\
\hline Turks \& Caicos Islands & 14 & 0 & 13 \\
\hline Vanuatu & 19 & 0 & 8 \\
\hline Virgin Islands (U.S) & 27 & 0 & 0 \\
\hline
\end{tabular}


Table 3: Foreign Direct Investment net outflow (\% of GDP)

\begin{tabular}{|c|c|c|c|}
\hline & (1) & $(2)$ & (3) \\
\hline \multicolumn{4}{|l|}{ Dep. variable: Agreement form } \\
\hline \multirow[t]{2}{*}{ Distance } & -0.0619 & -0.0802 & 0.0024 \\
\hline & $(0.0509)$ & $(0.0550)$ & $(0.0604)$ \\
\hline \multirow[t]{2}{*}{ GDP } & $-0.3537^{* *}$ & $-0.4850^{* *}$ & -0.3250 \\
\hline & $(0.1738)$ & $(0.2018)$ & $(0.2230)$ \\
\hline \multirow[t]{2}{*}{ FDI net outflow (\%GDP) } & $-0.2798 * * *$ & $-0.2328^{* * *}$ & $-0.3444^{* * *}$ \\
\hline & $(0.0552)$ & $(0.0587)$ & $(0.0754)$ \\
\hline \multirow[t]{2}{*}{ Governance index } & $1.4362^{* * *}$ & $0.7394^{* * *}$ & $1.1028^{* * *}$ \\
\hline & $(0.2156)$ & $(0.1496)$ & $(0.2183)$ \\
\hline \multirow[t]{2}{*}{ ODA eligibility } & 0.2018 & 0.1454 & $0.4076^{*}$ \\
\hline & $(0.1422)$ & $(0.1813)$ & $(0.2105)$ \\
\hline \multirow{2}{*}{ GDP per capita difference } & $0.7062^{* * *}$ & $0.5213^{* * *}$ & $0.7790 * * *$ \\
\hline & $(0.0701)$ & $(0.0872)$ & $(0.0909)$ \\
\hline \multirow[t]{2}{*}{ Common language } & $-0.2461^{* *}$ & $-0.2833^{* *}$ & $-0.3046^{* *}$ \\
\hline & $(0.1130)$ & $(0.1297)$ & $(0.1397)$ \\
\hline \multirow[t]{2}{*}{ Treaty before 1998} & & $0.3774^{* *}$ & $0.4434^{* *}$ \\
\hline & & $(0.1563)$ & $(0.1772)$ \\
\hline \multirow[t]{2}{*}{ Bilateral portfolio outflow } & & $0.1139^{* *}$ & \\
\hline & & $(0.0431)$ & \\
\hline \multirow[t]{2}{*}{ Bilateral FDI } & & & 0.0065 \\
\hline & & & $(0.0450)$ \\
\hline \multirow[t]{2}{*}{$\kappa_{1}$} & $1.7820 * * *$ & $1.0437^{* * *}$ & $1.4921^{* * *}$ \\
\hline & $(0.2540)$ & $(0.1940)$ & $(0.2414)$ \\
\hline \multirow[t]{2}{*}{$\kappa_{2}$} & $2.3235^{* * *}$ & $1.6586^{* * *}$ & $2.1064^{* * *}$ \\
\hline & $(0.2581)$ & $(0.1993)$ & $(0.2484)$ \\
\hline$\tau_{i}$ & 0.9018 & 0.8697 & 0.9413 \\
\hline Log Likelihood & -622.3963 & -498.9385 & -422.9698 \\
\hline $\mathrm{N}$ & 864 & 635 & 569 \\
\hline
\end{tabular}

${ }^{*} \mathrm{p}<0.1,{ }^{* *} \mathrm{p}<0.05,{ }^{* * *} \mathrm{p}<0.001$. The standard deviations are in brackets. $\kappa$ represent the estimated cut-off points.

$\tau_{i}$ is the estimated standard deviation of the haven-specific random intercept. The data is standardized. 
Table 4: Savings Tax Directive

\begin{tabular}{|c|c|c|c|}
\hline & (1) & $(2)$ & $(3)$ \\
\hline \multicolumn{4}{|l|}{ Dep. variable: agreement form } \\
\hline \multirow[t]{2}{*}{ Distance } & -0.0705 & -0.0756 & -0.0293 \\
\hline & $(0.0444)$ & $(0.0507)$ & $(0.0539)$ \\
\hline \multirow[t]{2}{*}{ GDP } & $-0.4485^{* *}$ & $-0.7488^{* * *}$ & $-0.8046^{* * *}$ \\
\hline & $(0.1472)$ & $(0.2119)$ & $(0.2063)$ \\
\hline \multirow[t]{2}{*}{ Governance index } & $0.8723^{* * *}$ & $0.6736^{* * *}$ & $0.9547^{* * *}$ \\
\hline & $(0.1298)$ & $(0.1470)$ & $(0.1667)$ \\
\hline \multirow[t]{2}{*}{ ODA eligibility } & $0.4711^{* * *}$ & $0.3303^{*}$ & $0.3989^{* *}$ \\
\hline & $(0.1261)$ & $(0.1879)$ & $(0.1945)$ \\
\hline \multirow[t]{2}{*}{ GDP per capita difference } & $0.3636^{* * *}$ & $0.3138^{* * *}$ & $0.6304^{* * *}$ \\
\hline & $(0.0461)$ & $(0.0677)$ & $(0.0793)$ \\
\hline \multirow[t]{2}{*}{ Common language } & -0.1061 & $-0.2240^{*}$ & $-0.2763^{* *}$ \\
\hline & $(0.0998)$ & $(0.1222)$ & $(0.1292)$ \\
\hline \multirow[t]{2}{*}{ Common Savings Tax Directive } & 0.1489 & 0.0674 & -0.0558 \\
\hline & $(0.1162)$ & $(0.1473)$ & $(0.1546)$ \\
\hline \multirow[t]{2}{*}{ Treaty before 1998} & & $0.4475^{* *}$ & $0.4528 * *$ \\
\hline & & $(0.1509)$ & $(0.1679)$ \\
\hline \multirow[t]{2}{*}{ Bilateral portfolio outflow } & & $0.1080^{* *}$ & \\
\hline & & $(0.0418)$ & \\
\hline \multirow[t]{2}{*}{ Bilateral FDI } & & & -0.0098 \\
\hline & & & $(0.0399)$ \\
\hline \multirow[t]{2}{*}{$\kappa_{1}$} & $1.722^{* * *}$ & $1.25^{* * *}$ & $1.533^{* * *}$ \\
\hline & $(0.1813)$ & $(0.2192)$ & $(0.2281)$ \\
\hline \multirow[t]{2}{*}{$\kappa_{2}$} & $2.135^{* * *}$ & $1.748^{* * *}$ & $2.018^{* * *}$ \\
\hline & $(0.1841)$ & $(0.222)$ & $(0.2329)$ \\
\hline \multirow{2}{*}{$\tau_{i}$} & $1.018^{* * *}$ & $0.7932^{* * *}$ & $0.9707^{* * *}$ \\
\hline & $(0.1026)$ & $(0.1080)$ & (0.1179) \\
\hline Log Likelihood & -831.1884 & -628.1058 & -537.8952 \\
\hline $\mathrm{N}$ & 1134 & 803 & 730 \\
\hline
\end{tabular}

$\mathrm{p}<0.1, * * \mathrm{p}<0.05, * * * \mathrm{p}<0.001$.

The standard deviations are in brackets.

$\kappa$ represent the estimated cut-off points.

$\tau_{i}$ is the estimated standard deviation of the random intercept.

The data is standardized. 
Table 5: Excluding OECD tax haven countries.

\begin{tabular}{|c|c|c|c|}
\hline & (1) & $(2)$ & (3) \\
\hline \multicolumn{4}{|l|}{ Dep. variable: agreement form } \\
\hline Distance & $\begin{array}{c}-0.0669 \\
(0.0511)\end{array}$ & $\begin{array}{c}-0.0602 \\
(0.0519)\end{array}$ & $\begin{array}{r}-0.0181 \\
(0.0571)\end{array}$ \\
\hline GDP & $-2.5133^{* * *}$ & $-0.7759^{*}$ & $\begin{array}{r}-1.2229^{* *} \\
(0.4374)\end{array}$ \\
\hline Governance index & $\begin{array}{r}(0.3564) \\
0.9469^{* * *} \\
(0.1888)\end{array}$ & $\begin{array}{r}(0.4077) \\
0.5130 * * * \\
(0.1263)\end{array}$ & $\begin{array}{r}(0.4374) \\
0.9707^{* * *} \\
(0.1713)\end{array}$ \\
\hline ODA eligibility & $\begin{array}{r}(0.1888) \\
0.3621^{* *} \\
(0.1278)\end{array}$ & $\begin{array}{r}(0.1263) \\
0.3772^{* *} \\
(0.1829)\end{array}$ & $\begin{array}{c}(0.1713) \\
0.3689^{*} \\
(0.2165)\end{array}$ \\
\hline GDP per capita difference & $\begin{array}{r}0.3427^{* * *} \\
(0.0515)\end{array}$ & $\begin{array}{r}0.1571^{* *} \\
(0.0636)\end{array}$ & $\begin{array}{r}0.6008^{* * *} \\
(0.0856)\end{array}$ \\
\hline Common language & $\begin{array}{r}-0.1010 \\
(0.1062)\end{array}$ & $\begin{array}{r}-0.1383 \\
(0.1267)\end{array}$ & $\begin{array}{r}-0.2217 \\
(0.1372)\end{array}$ \\
\hline Treaty before 1998 & & $\begin{array}{r}0.4954^{* *} \\
(0.1602)\end{array}$ & $\begin{array}{r}0.4678^{* *} \\
(0.1753)\end{array}$ \\
\hline Bilateral portfolio outflow & & $\begin{array}{l}.0978^{* *} \\
(0.0443)\end{array}$ & \\
\hline Bilateral FDI & & & $\begin{array}{r}-0.0149 \\
(0.0401)\end{array}$ \\
\hline$\kappa_{1}$ & $\begin{array}{r}2.227^{* * *} \\
(0.2612)\end{array}$ & $\begin{array}{r}1.3078^{* * *} \\
(0.2034)\end{array}$ & $\begin{array}{r}1.6447^{* * *} \\
(0.2466)\end{array}$ \\
\hline$\kappa_{2}$ & $\begin{array}{r}2.6158^{* * * *} \\
(0.2639)\end{array}$ & $\begin{array}{r}1.7731^{* * *} \\
(0.2067)\end{array}$ & $\begin{array}{r}2.0890^{* * *} \\
(0.2512)\end{array}$ \\
\hline$\tau_{i}$ & 0.9432 & 0.9269 & 0.9498 \\
\hline Log Likelihood & -767.2385 & -568.6082 & -485.2172 \\
\hline $\mathrm{N}$ & 1053 & 730 & 668 \\
\hline
\end{tabular}

${ }^{*} \mathrm{p}<0.1,{ }^{* *} \mathrm{p}<0.05,{ }^{* * *} \mathrm{p}<0.001$. The standard deviations are in brackets. $\kappa$ represent the estimated cut-off points.

$\tau_{i}$ is the estimated standard deviation of the haven-specific random intercept. The data is standardized. 
Table 6: Excluding Nordic countries

\begin{tabular}{|c|c|c|c|}
\hline & (1) & $(2)$ & $(3)$ \\
\hline \multicolumn{4}{|l|}{ Dep. variable: agreement form } \\
\hline \multirow[t]{2}{*}{ Distance } & $-0.1116^{* *}$ & -0.0680 & -0.0570 \\
\hline & $(0.0500)$ & $(0.05658)$ & $(0.0635)$ \\
\hline \multirow[t]{2}{*}{ GDP } & $-0.4050^{* *}$ & $-0.5415^{* *}$ & $-0.5364^{*}$ \\
\hline & $(0.1648)$ & $(0.2685)$ & $(0.3012)$ \\
\hline \multirow[t]{2}{*}{ Governance index } & $0.5130^{* * *}$ & $0.7675^{* * *}$ & $0.6486^{* *}$ \\
\hline & $(0.1280)$ & $(0.1987)$ & $(0.2402)$ \\
\hline \multirow[t]{2}{*}{ ODA eligibility } & .1392 & 0.1547 & 0.1235 \\
\hline & $(0.1340)$ & $(0.2428)$ & $(0.2979)$ \\
\hline \multirow[t]{2}{*}{ GDP per capita difference } & $0.2115^{* * *}$ & $0.1934^{* *}$ & $0.4290^{* * *}$ \\
\hline & $(0.0530)$ & $(0.0872)$ & $(0.1191)$ \\
\hline \multirow[t]{2}{*}{ Common language } & -0.0635 & -0.1527 & -0.1346 \\
\hline & $(0.1090)$ & $(0.1295)$ & $(0.1410)$ \\
\hline \multirow[t]{2}{*}{ Treaty before 1998} & & 0.0481 & 0.1990 \\
\hline & & $(0.1921)$ & $(0.2049)$ \\
\hline \multirow[t]{2}{*}{ Bilateral portfolio outflow } & & $0.1362^{* *}$ & \\
\hline & & $(0.0446)$ & \\
\hline \multirow[t]{2}{*}{ Bilateral FDI } & & & 0.0134 \\
\hline & & & $(0.0429)$ \\
\hline \multirow[t]{2}{*}{$\kappa_{1}$} & $1.1793^{* * *}$ & $1.2756^{* * *}$ & $1.2092^{* * *}$ \\
\hline & $(0.1677)$ & $(0.2781)$ & $(0.3433)$ \\
\hline \multirow[t]{2}{*}{$\kappa_{2}$} & $1.6279^{* * *}$ & $1.7655^{* * *}$ & $1.7315^{* * *}$ \\
\hline & $(0.1705)$ & $(0.2830)$ & $(0.3470)$ \\
\hline$\tau_{i}$ & 0.8201 & 0.5943 & 0.7125 \\
\hline Log Likelihood & -642.9783 & -508.8957 & -407.1334 \\
\hline $\mathrm{N}$ & 924 & 672 & 568 \\
\hline
\end{tabular}

$\mathrm{p}<0.1,{ }^{* *} \mathrm{p}<0.05, * * * \mathrm{p}<0.001$.

The standard deviations are in brackets.

$\kappa$ represent the estimated cut-off points.

$\tau_{i}$ is the estimated standard deviation of the random intercept.

The data is standardized. 
Table 7: Population-averaged marginal effects

\begin{tabular}{|c|c|c|c|}
\hline & (1) & $(2)$ & $(3)$ \\
\hline \multicolumn{4}{|l|}{ Category: No Agreement } \\
\hline GDP & 0.1078 & 0.3772 & 0.2045 \\
\hline World Governance Average & -0.2132 & -0.2038 & -0.2405 \\
\hline ODA Eligibility & -0.0988 & -0.0459 & -0.1007 \\
\hline Distance & 0.0173 & 0.0201 & -0.0078 \\
\hline Difference in GDP & -0.0845 & -0.0795 & -0.1607 \\
\hline Common Language & 0.0292 & 0.0575 & 0.0657 \\
\hline Treaty before 1998 & - & -0.1149 & -0.1155 \\
\hline Bilateral portfolio outflow & - & -0.0288 & - \\
\hline Bilateral foreign direct investment & - & - & 0.0021 \\
\hline \multicolumn{4}{|l|}{ Category: DTC } \\
\hline GDP & -0.0216 & -0.0891 & -0.0415 \\
\hline World Governance Average & 0.0427 & 0.0482 & 0.0488 \\
\hline ODA Eligibility & 0.0200 & 0.0109 & 0.0207 \\
\hline Distance & -0.0035 & -0.0047 & 0.0016 \\
\hline Difference in GDP & 0.0169 & 0.0188 & 0.0326 \\
\hline Common Language & -0.0061 & -0.0146 & -0.0145 \\
\hline Treaty before 1998 & - & 0.0238 & 0.0202 \\
\hline Bilateral portfolio outflow & - & 0.0068 & - \\
\hline Bilateral foreign direct investment & - & - & -0.0004 \\
\hline \multicolumn{4}{|l|}{ Category: TIEA } \\
\hline GDP & -0.0862 & -0.2881 & -0.1630 \\
\hline World Governance Average & 0.1705 & 0.1557 & 0.1917 \\
\hline ODA Eligibility & 0.0788 & 0.0351 & 0.0801 \\
\hline Distance & -0.0138 & -0.0153 & 0.0062 \\
\hline Difference in GDP & 0.0676 & 0.0607 & 0.1281 \\
\hline Common Language & -0.0232 & -0.0430 & -0.0511 \\
\hline Treaty before 1998 & - & 0.0911 & 0.0952 \\
\hline Bilateral portfolio outflow & - & 0.0220 & - \\
\hline Bilateral foreign direct investment & - & - & -0.0017 \\
\hline $\mathrm{N}$ & 1134 & 803 & 730 \\
\hline
\end{tabular}




\section{Data Appendix}

\section{Tax Haven list.}

Source: Hines and Rice (1994) and OECD (2000).

Andorra, Anguilla, Antigua and Barbuda, Aruba*, Bahamas, Bahrain, Barbados, Belize, Bermuda, British Virgin Islands, Cayman Islands, Cook Islands, Cyprus, Dominica, Gibraltar, Grenada, Guernsey, Hong Kong**, Ireland $^{* *}$, Isle of Man, Jersey, Jordan*, Lebanon*, Liberia, Liechtenstein, Luxembourg**, Macao**, Maldives, Malta, Marshall Islands, Mauritius*, Monaco, Montserrat, Nauru*, Netherlands Antilles, Niue*, Panama, St. Kitts and Nevis, St. Lucia, St. Vincent and the Grenadines, Samoa*, San Marino*, Seychelles*, Singapore**, Switzerland**, Tonga*, Turks and Caicos Islands, Vanuatu, Virgin Islands (U.S).*

* : Appears only in the OECD (2000) list.

**: Appears only in the Hines and Rice (1994) list.

\section{OECD countries.}

Source: OECD.

Available at www.oecd.org

Australia, Austria, Belgium, Canada, Czech Republic, Denmark, Finland, France, Germany, Greece, Hungary, Iceland, Italy, Japan, Korea, Mexico, Netherlads, New Zealand, Norway, Poland, Portugal, Slovak Republic, Spain, Sweden, Turkey, United Kingdom, United States.

\section{Agreement form.}

Source: International Bureau of Fiscal Documentation Database and OECD Global Forum for Transparency and Exchange of Information for Tax Purposes. http://eoi-tax.org/

Bilateral categorical variable indicating 0 if no agreement has been signed between a tax haven and a OECD country, 1 if a DTC which meets the international standards and has the strong information exchange article (Paragraph 4 and 5 of Article 26) and 2 if a TIEA has been signed.

\section{GDP.}

Source: the World Bank's Development Indicators (WDI), available at http://data.worldbank.org/

Data are in current U.S. dollars, for 2006. Dollar figures for GDP are 
converted from domestic currencies using single year official exchange rates. For a few countries where the official exchange rate does not reflect the rate effectively applied to actual foreign exchange transactions, an alternative conversion factor is used. For countries and territories for which GDP data are missing in WDI, Data from the UN's National Accounts Main Aggregats Database is used http://data.un.org/

\section{Governance Index.}

Source: Kaufmann, Kraay and Mastruzzi (2005).

This index is obtained by the taking the unweighted mean of the 6 availabe governance measures constructed by Kaufmann et al. (2005) for the year 2009. It is a continuous variable over the approximate interval $(-2.5$, 2.5), normalized to have mean 0 and standard deviation 1, with higher values indicating better governance. Data is available for only 42 tax haven jurisdictions.

\section{Official Development Aid Eligibility.}

Source: OECD Development Cooperation Directorate.

Indicator variable ( $=1$ if a country is on the 2006 DAC List of ODA Recipients). The DAC List of ODA Recipients shows all countries and territories eligible to receive official development assistance (ODA). These consist of all low and middle income countries based on gross national income (GNI) per capita as published by the World Bank, with the exception of G8 members, EU members, and countries with a firm date for entry into the EU. The list also includes all of the Least Developed Countries (LDCs) as defined by the United Nations (UN).

\section{Foreign Direct Investment, net outflow (\% of GDP).}

Source: the World Bank's Development Indicators (WDI)

Available at http://data.worldbank.org/

This variable shows net outflows of investment from the reporting economy to the rest of the world and is divided by GDP for the year 2006. Foreign direct investment are the net inflows of investment to acquire a lasting management interest (10 percent or more of voting stock) in an enterprise operating in an economy other than that of the investor. It is the sum of equity capital, reinvestment of earnings, other long-term capital, and short-term 
capital as shown in the balance of payments.

\section{Difference in GDP per capita.}

Source: the World Bank's Development Indicators (WDI).

Available at http://data.worldbank.org/

Variable is constructed using the absolute value of the difference betwen a given country pair's GDP per capita.

Data are in current U.S. dollars, for 2006. Dollar figures for GDP are converted from domestic currencies using single year official exchange rates. For a few countries where the official exchange rate does not reflect the rate effectively applied to actual foreign exchange transactions, an alternative conversion factor is used. For countries and territories for which GDP per capita data are missing in WDI, Data from the UN's National Accounts Main Aggregates Database is used http://data.un.org/

\section{Bilateral Portfolio Outflow.}

Source: IMF's Coordinated Portfolio Investment Survey (CPIS).

Available at http://www.imf.org/external/np/sta/pi/cpis.htm.

Geographic breakdown of total portfolio investment assets from OECD countries to tax havens in current million U.S dollars, for 2006.

\section{Bilateral FDI.}

Source: OECD International direct investment database.

Available at http://stats.oecd.org.

The sum of inward and outward foreign direct investment flows from OECD countries to tax havens. Data is measured in millions U.S dollars, for year 2006 .

\section{Treaty before 1998.}

Source: International Bureau of Fiscal Documentation Database.

Indicator variable $(=1$ if a country pair had a tax treaty in force before 1998).

\section{Distance.}

Source: GEODist Database (CEPII) available at http://www.cepii.fr.

Variable measures simple distances in $\mathrm{km}$ which uses the lattitudes and longitudes of the most important cities/agglomerations.

\section{Common language.}


Source: GEODist Database (CEPII) available at http://www.cepii.fr.

Indicator variable $(=1$ if more than $9 \%$ of population of each country pair speak the same language). 


\section{References}

G20 declaration on strengthening the financial system, 2nd april 2009, london.

Agresti, A. (2010). Analysis of Ordinal Categorical Data. Wiley Series in Probability and Statistics. Wiley.

Bacchetta, P. and M. Espinosa (2000, May). Exchange-of-information clauses in international tax treaties. International Tax and Public Finance $7(3), 275-293$.

Bacchetta, P. and M. P. Espinosa (1995, August). Information sharing and tax competition among governments. Journal of International Economics 39(1-2), 103-121.

Chisik, R. and R. B. Davies (2004). Asymmetric FDI and tax-treaty bargaining: theory and evidence. Journal of Public Economics 88(6), 1119 -1148 .

Desai, M. A., C. F. Foley, and J. J. Hines (2006a). The demand for tax haven operations. Journal of Public Economics 90(3), 513-531.

Desai, M. A., C. F. Foley, and J. J. Hines (2006b). Do tax havens divert economic activity? Economics Letters 90(2), 219-224.

Dharmapala, D. (2008). What problems and opportunities are created by tax havens? Oxford Review of Economic Policy 24(4), 661-679.

Elsayyad, M. and K. A. Konrad (2011). Fighting multiple tax havens. Journal of International Economics (0), -.

Greene, W. (2003). Econometric analysis. Prentice Hall.

Hong, Q. and M. Smart (2010). In praise of tax havens: International tax planning and foreign direct investment. European Economic Review $54(1), 82-95$.

Huizinga, H. and G. Nicodeme (2004, June). Are international deposits tax-driven. Journal of Public Economics 88(6), 1093-1118. 
Huizinga, H. and S. B. Nielsen (2002). Withholding taxes or information exchange: the taxation of international interest flows. Journal of Public Economics 87(1), 39 - 72. <ce:title>Proceedings of the Trans Atlantic Public Economics Seminar on "Taxation of Financial Incomet" 22-24 May, 2000. $</$ ce:title $>$.

Johannesen, N. (2010). Imperfect tax competition for profits, asymmetric equilibrium and beneficial tax havens. Journal of International Economics $81(2), 253-264$.

Kaufmann, D., A. Kraay, and M. Mastruzzi (2010, September). The worldwide governance indicators : methodology and analytical issues. Policy Research Working Paper Series 5430, The World Bank.

Keen, M. and J. Ligthart (2006, May). Incentives and information exchange in international taxation. International Tax and Public Finance 13(2), 163-180.

Keen, M. and J. E. Ligthart (2007, 09). Revenue sharing and information exchange under non-discriminatory taxation. Scandinavian Journal of Economics 109(3), 487-504.

Kudrle, R. (2009). Did blacklisting hurt the tax havens? Journal of Money Laundering Control 12, 33-49.

Ligthart, J. M. V. and J. Voget (2011). The determinants of double tax treaty formation. mimeo, - .

OECD (1998). Harmful Tax Competition: An Emerging Global Issue. OECD Publishing.

Rabe-Hesketh, S. and A. Skrondal (2008). Multilevel and longitudinal modeling using stata. Stata Press.

Slemrod, J. and J. D. Wilson (2009). Tax competition with parasitic tax havens. Journal of Public Economics 93(11-12), 1261-1270.

Torvik, R. (2009). Why are tax havens more harmful to developing countries than to other countries? Report from the Government Commission on Capital Flight from Poor Countries, 155 - 194. 